\title{
ANALISIS KUALITAS AIR TANAH DI KAWASAN PESISIR DESA LABUHAN KERTASARI, SUMBAWA BARAT
}

\author{
Andi Maria Ulfa ${ }^{*}$, Amirul Hilmi ${ }^{2}$, Syarifah Rabiatul Adawiah ${ }^{3}$ \\ ${ }^{1}$ Program Studi Pemanfaatan Sumberdaya Perikanan Universitas Cordova \\ ${ }^{2}$ Program Studi Teknik Industri Universitas Cordova \\ ${ }^{3}$ Jurusan Kimia UIN Alauddin Makassar
}

yayaqe06011991@gmail.com

\begin{tabular}{l} 
Artikel Info \\
Diterima \\
tanggal \\
22.02 .2021 \\
Disetujui \\
publikasi \\
tanggal \\
30.04.2021 \\
Kata kunci : \\
Kawasan \\
Pesisir, Kualitas \\
Air, Desa \\
Labuhan \\
Kertasari \\
\hline
\end{tabular}

\section{ABSTRACT}

The purpose of this study is to analyze the quality of groundwater in the coastal area of Labuhan Kertasari Village, West Sumbawa Regency. The research method used was direct observation into the field, and the sample points were carried out by purposive sampling method, namely as many as 40 points. Water quality analysis is carried out by measuring the values of physical and chemical parameters including $\mathrm{pH}$, TDS, and DO. Measurement of research parameters was carried out in situ. The results showed that the quality of water in Labuhan Kertasari Village showed that there were $7.5 \%$ belonging to class I, in accordance with the established water quality standards, namely at SW25, SW26 and SW28 with TDS values respectively: $893 \mathrm{mg} / \mathrm{L} ; 836 \mathrm{mg} / \mathrm{L} ; 904 \mathrm{mg} / \mathrm{L}$, the $\mathrm{pH}$ values are respectively: 7.36; $7.25 ; 7,76$ and DO values, respectively: 7,2; 6.9; 7.4. The water at the sample point S26 has the best quality of the 40 sample points.

\section{PENDAHULUAN}

Air merupakan salah satu sumberdaya yang sangat penting dalam kehidupan manusia. Keberadaan air harus dijaga dan dikelola dengan baik serta perlu dilakukan pengendalian pencemaran air. Dasar pengelolaan dan pengendalian pencemaran air berpedoman pada peraturan pemerintah No. 82 Tahun 2001 tentang Pengelolaan kualitas air dan pengendalian

http://dx.doi.org/10.23960/aec.v6.i1.2021.p22-32 
pencemaran air. Pencemaran air sering kali terjadi karena disebabkan oleh penggunaan bahanbahan yang kita gunakan sehari-hari secara terus-menerus seperti, deterjen, pestisida, pembakaran batubara dan oli, dan lain-lain (Ahuja, 2013).

Penelitian ini dilaksanakan di kawasan pesisir Desa Labuhan Kertasari. Secara administrasi Desa Labuhan Kertasari merupakan salah satu desa yang berada di Kecamatan Taliwang Kabupaten Sumbawa Barat dengan luas wilayah 3.667 Ha. Kawasan pesisir Desa Labuhan Kertasari merupakan salah satu desa minapolitan yang dicanangkan oleh pemerintah daerah Kabupaten Sumbawa Barat. Desa Labuhan Kertasari merupakan daerah yang cepat berkembang karena memiliki penghuni yang relatif padat. Perkembangan pesisir dan laut di daerah ini ditandai dengan banyaknya usaha budidaya rumput laut. Secara umum perkembangannya masih terkendali dan belum berdampak negatif terhadap lingkungan dan kestabilan pantai (Lugra et al., 2003).

Sebagai kawasan minapolitan, tentunya Desa Labuhan Kertasari memerlukan air yang tidak sedikit, sehingga perlu dilakukan analisis kualitas air di kawasan pesisir Desa Labuhan Kertasari. Analisis yang dilakukan meliputi pengukuran parameter fisika dan kimia air, yaitu pH, TDS dan DO. Dari ketiga parameter ini diharapkan dapat memberikan gambaran kualitas air tanah sesuai dengan baku mutu yang ditetapkan. Sehingga tujuan dari penelitian ini yaitu menganalisis kualitas air tanah dan membandingkannya dengan peraturan yang berlaku.

\section{METODE}

\section{Lokasi Penelitian}

Penelitian ini dilakukan di wilayah pesisir Desa Labuhan Kertasari, Kecamatan Taliwang, Kabupaten Sumbawa Barat.

\section{Alat dan Bahan}

Alat yang digunakan pada penelitian ini yaitu $\mathrm{pH}$ meter, TDS meter, Disolved Oxygen meter, GPS dan botol sampel. Bahan yang digunakan pada penelitian ini yaitu sampel dan aquades.

\section{Teknik Pengambilan Sampel}

Metode penelitian ini yaitu metode observasi, yaitu pengambilan data primer dengan melakukan pengukuran langsung di lapangan. Penentuan titik sampel dilakukan dengan metode 
purposive sampling, yaitu salah satu teknik pengambilan sampel dengan ketentuan tertentu sesuai kebutuhan penelitian.

Jumlah titik sampel pada penelitian ini sebanyak 40 titik, sampel yang diambil merupakan sampel air sumur yang aktif digunakan oleh warga. Sampel diambil pada dasar sumur dengan menggunakan botol yang dimodifikasi dan diberi pemberat.

\section{Pengumpulan dan Analisis Data}

Jenis data yang dikumpulkan yaitu, koordinat titik sampel, kedalaman dan jenis sumur, $\mathrm{pH}$, TDS, dan DO. Pengukuran dari parameter pH, TDS dan DO dilakukan secara insitu dengan menggunakan alat Lutron WA 2017SD.

Analisis data dilakukan dengan menggunakan software Klaeda Graph, Excel dan Surfer 8. Analisis data dilakukan dengan membuat grafik regresi linier sederhana, membuat peta kontur dan tabel. Hasil analisis kemudian dibandingkan dengan standar baku mutu air pada PP RI N0 82 Tahun 2001 tentang pengelolaan kualitas air dan pengendalian pencemaran air (Tabel 1).

\section{HASIL DAN PEMBAHASAN}

\section{Hasil Pengukuran Parameter Penelitian}

Pada penelitian ini, parameter yang diukur yaitu pH, TDS dan DO, yaitu untuk mengetahui kualitas air di kawasan pesisir Desa Labuhan Kertasari.

Pengukuran setiap parameter dilakukan secara insitu dan ditentukan letak titik koordinat dengan menggunakan GPS. Penentuan titik koordinat diperlukan dalam pembuatan peta kontur sebaran pH, DO dan TDS. Hasil pengukuran dari setiap parameter dapat dilihat pada Tabel 2.

Tabel 1. Baku mutu air berdasarkan kelas (PP RI NO 82 TAHUN 2001)

\begin{tabular}{lllllll}
\hline \multirow{2}{*}{\multicolumn{2}{c}{ Parameter }} & \multirow{2}{*}{ Satuan } & \multicolumn{5}{c}{ Kelas } \\
\cline { 3 - 7 } & & \multicolumn{2}{c}{ I } & \multicolumn{1}{c}{ II } & III & \multicolumn{1}{c}{ IV } \\
\hline Residu Terlarut (TDS) & $\mathrm{mg} / \mathrm{L}$ & 1000 & 1000 & 1000 & 2000 \\
$\mathrm{pH}$ & & $6-9$ & $6-9$ & $6-9$ & $5-9$ \\
DO & $\mathrm{mg} / \mathrm{L}$ & 6 & 4 & 3 & 0 \\
Klorida & $\mathrm{mg} / \mathrm{L}$ & 1 & - & - & - \\
\hline
\end{tabular}

http://dx.doi.org/10.23960/aec.v6.i1.2021.p22-32 
Tabel 2. Hasil pengukruan parameter kimia dan fisika di 40 lokasi sampel

\begin{tabular}{|c|c|c|c|c|c|c|c|}
\hline $\begin{array}{c}\text { Titik } \\
\text { Sampel }\end{array}$ & $\begin{array}{l}\text { Lintang } \\
\text { Selatan }\end{array}$ & $\begin{array}{l}\text { Bujur } \\
\text { Timur }\end{array}$ & $\mathbf{p H}$ & $\begin{array}{c}\text { TDS } \\
(\mathrm{mg} / \mathrm{L})\end{array}$ & $\begin{array}{c}\text { DO } \\
(\mathrm{mg} / \mathrm{L})\end{array}$ & $\begin{array}{c}\text { Kedalaman } \\
(\mathrm{cm})\end{array}$ & $\begin{array}{c}\text { Jenis } \\
\text { Sumur }\end{array}$ \\
\hline SW1 & 476425 & 9035640 & 7,88 & 1480 & 8.2 & 310 & Sumur Gali \\
\hline SW2 & 476601 & 9035803 & 8.44 & 1187 & 8 & 170 & Sumur Gali \\
\hline SW3 & 476641 & 9036135 & 7.76 & 2470 & 7.5 & 220 & Sumur Gali \\
\hline SW4 & 476673 & 9035983 & 7.6 & 3060 & 8.2 & 190 & Sumur Gali \\
\hline SW5 & 476643 & 9036132 & 8.3 & 3040 & 8.1 & 189 & Sumur Gali \\
\hline SW6 & 476835 & 9036226 & 7.54 & 1213 & 7.3 & 210 & Sumur Gali \\
\hline SW7 & 476805 & 9036291 & 8.03 & 2000 & 7.5 & 280 & Sumur Gali \\
\hline SW8 & 476782 & 9036268 & 8.1 & 5770 & 7.8 & 279 & Sumur Gali \\
\hline SW9 & 476827 & 9036276 & 8.23 & 1970 & 7.5 & 285 & Sumur Gali \\
\hline SW10 & 476806 & 9036242 & 7.58 & 1450 & 7.5 & 270 & Sumur Gali \\
\hline SW11 & 476803 & 9036216 & 8.29 & 1041 & 7.3 & 289 & Sumur Gali \\
\hline SW12 & 476631 & 9036376 & 7.26 & 2790 & 7.6 & 184 & Sumur Gali \\
\hline SW13 & 476609 & 9036518 & 7.2 & 3370 & 7.5 & 240 & Sumur Gali \\
\hline SW14 & 476570 & 9036517 & 8.42 & 1560 & 7.9 & 156 & Sumur Gali \\
\hline SW15 & 476576 & 9036489 & 7.57 & 3070 & 7.9 & 207 & Sumur Gali \\
\hline SW16 & 476605 & 9036233 & 7.42 & 1306 & 7.7 & 228 & Sumur Gali \\
\hline SW17 & 476651 & 9037042 & 7.36 & 2040 & 3.7 & 210 & Sumur Gali \\
\hline SW18 & 476559 & 9037276 & 8.02 & 1106 & 7.8 & 200 & Sumur Gali \\
\hline SW19 & 476532 & 9037275 & 7.58 & 3070 & 7.2 & 184 & Sumur Gali \\
\hline SW20 & 476603 & 9037247 & 7.38 & 5040 & 7.1 & 284 & Sumur Gali \\
\hline SW21 & 476502 & 9037299 & 7.44 & 3070 & 7.3 & 189 & Sumur Gali \\
\hline SW22 & 476501 & 9037374 & 7.32 & 4000 & 7.4 & 210 & Sumur Gali \\
\hline SW23 & 476393 & 9037422 & 7.79 & 3700 & 7.1 & 450 & Sumur Gali \\
\hline SW24 & 476391 & 9037454 & 7.17 & 1700 & 7.6 & 2800 & sumur bor \\
\hline SW25 & 477297 & 9038288 & 7.36 & 893 & 7.2 & 740 & Sumur Gali \\
\hline SW26 & 477334 & 9038328 & 7.25 & 836 & 6.9 & 545 & sumur gali \\
\hline SW27 & 477135 & 9037970 & 7.05 & 1471 & 5 & 700 & sumur bor \\
\hline SW28 & 477088 & 9038062 & 7.76 & 904 & 7.4 & 660 & sumur gali \\
\hline SW29 & 476227 & 9037487 & 7.69 & 2240 & 2.3 & 250 & Sumur Gali \\
\hline SW30 & 476531 & 9037563 & 7.45 & 1880 & 6.9 & 256 & sumur gali \\
\hline SW31 & 476573 & 9037591 & 6.78 & 5560 & 5.8 & 353 & Sumur Gali \\
\hline SW32 & 476443 & 9037652 & 7.17 & 1680 & 6.7 & 526 & sumur gali \\
\hline SW33 & 476281 & 9037507 & 7.59 & 2790 & 6.6 & 405 & Sumur Gali \\
\hline SW34 & 476260 & 9037485 & 7.63 & 2460 & 6.7 & 370 & Sumur Gali \\
\hline SW35 & 476268 & 9037454 & 7.47 & 2240 & 6.8 & 375 & sumur gali \\
\hline SW36 & 476275 & 9037430 & 7.42 & 2860 & 6.4 & 300 & sumur gali \\
\hline SW37 & 476241 & 9037418 & 7.42 & 3960 & 6.3 & 340 & Sumur Gali \\
\hline SW38 & 476199 & 9037400 & 7.1 & 1610 & 5.7 & 3200 & sumur bor \\
\hline SW39 & 476197 & 9037483 & 7.41 & 2340 & 2.3 & 310 & Sumur Gali \\
\hline SW40 & 476316 & 9037426 & 7.43 & 2910 & 6.7 & 440 & Sumur Gali \\
\hline
\end{tabular}

Tabel 1 merupakan standar kualitas air berdasarkan kelasnya, dimana setiap kelas dapat dimanfaatakan sesuai peruntukannya. Air dengan kualitas air kelas I dapat digunakan sebagai air minum secara langsung tanpa pengolahan terlebih dahulu, sedangkan air kelas II dapat 
digunakan sebagai bahan baku air minum dan kebutuhan rumah tangga lainnya, dengan diolah terlebih dahulu.

Tabel 3. Statistik kualitas air hasil pengukuran

\begin{tabular}{lcccc}
\hline \multicolumn{1}{c}{ Parameter } & Sampel & Min & Max & Mean \\
\hline TDS $(\mathrm{mg} / \mathrm{L})$ & 40 & 836 & 5770 & 2428,425 \\
$\mathrm{pH}$ & 40 & 6,78 & 8,44 & 7,5915 \\
DO $(\mathrm{mg} / \mathrm{L})$ & 40 & 2,3 & 8,2 & 6,86 \\
\hline
\end{tabular}

Berdasarkan Tabel 1. dan Tabel 3. dapat dilihat kualitas air pada 40 titik sampel air sumur. Nilai minimum TDS sebesar $836 \mathrm{mg} / \mathrm{L}$ yaitu pada sampel SW26, yang paling tinggi pada sampel SW8 yaitu $5770 \mathrm{mg} / \mathrm{L}$. Nilai pH yang paling kecil sebesar 6,78 yaitu pada sampel SW31 dan yang paling tinggi pada sampel SW2 yaitu sebesar 8,44 . Sedangkan nilai DO yang paling kecil sebesar 2,3 mg/L pada sampel SW29 dan paling tinggi sebesar 8,2 mg/L pada sampel SW1.

Secara keseluruhan sebaran $\mathrm{pH}$, DO dan TDS memiliki nilai yang berbeda-beda pada setiap sampel, kualitas air akan berbeda-beda pada setiap tempat bergantung dari perubahan musim dan letak geografis (Salvi et al., 2014). Dari hasil analisis menunjukkan hanya 7,5\% air sumur yang memiliki kualitas kelas I, yaitu pada SW25, SW26 dan SW28 dengan nilai TDS berturut-turut: $893 \mathrm{mg} / \mathrm{L} ; 836 \mathrm{mg} / \mathrm{L} ; 904 \mathrm{mg} / \mathrm{L}$, nilai $\mathrm{pH}$ berturut-turut: 7,36; 7,25; 7,76 dan nilai DO berturut-turut: 7,2;6,9; 7,4. Air pada titik sampel S26 memiliki kualitas yang paling baik dari 40 titik sampel.

\section{Analisis Sebaran pH}

Peta kontur sebaran $\mathrm{pH}$ dibuat dengan menggunakan software Surfer 8. Hasil interpolasi data sebaran $\mathrm{pH}$ dapat dilihat pada Gambar 1. Dari peta kontur dapat dilihat seca visual bentuk sebaran $\mathrm{pH}$. Pada Gambar 1. Peta kontur berbentuk 1D dan 3D. Dari peta kontur 3D dapat dilihat secara jelas perbedaan lokasi yang memiliki $\mathrm{pH}$ rendah dan $\mathrm{pH}$ tinggi. Lokasi yang memiliki $\mathrm{pH}$ tinggi ditandai dengan puncak yang terbentuk dan memiliki warna biru. Untuk $\mathrm{pH}$ rendah, digambarkan dengan lembah dan berwarna cokelat. Berdasarkan lokasi penelitian, perbedaan nilai $\mathrm{pH}$ disebabkan oleh perbedaan interaksi tanah dengan air seperti pelarutan batu kapur oleh air (Ahmad et al., 2020).

http://dx.doi.org/10.23960/aec.v6.i1.2021.p22-32 


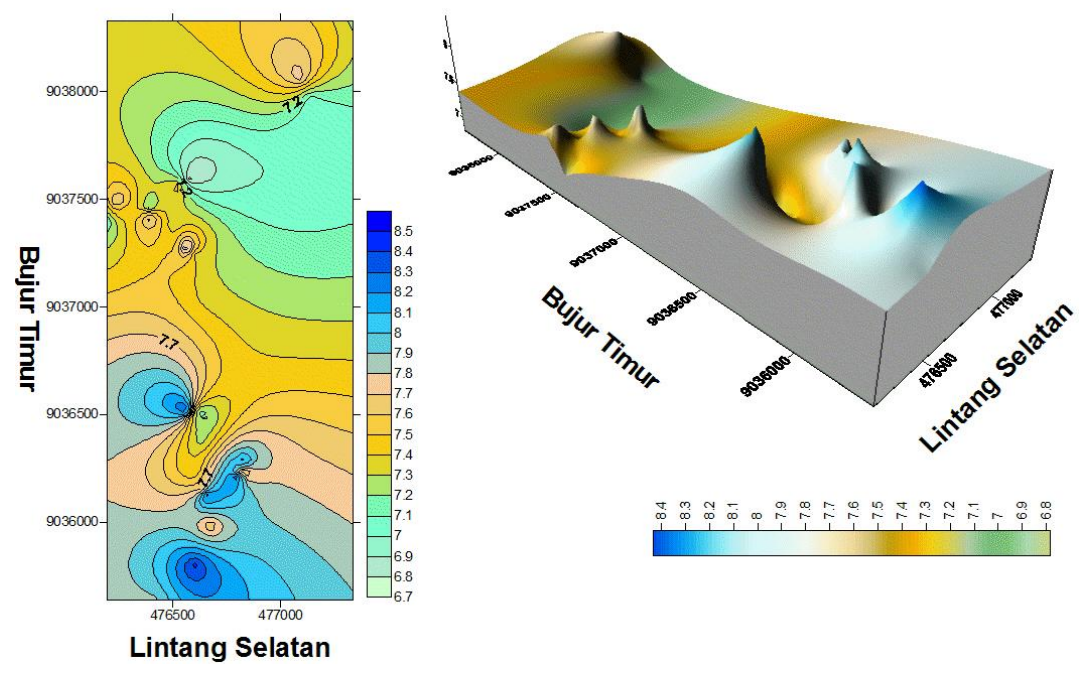

Gambar 1. Peta kontur sebaran $\mathrm{pH}$

Nilai pH dari 40 sampel berkisar antara 6,78-8,44, nilai pH ini sudah masuk dalam standar baku mutu air yang ditetapkan dalaam PP No.82 Tahun 2001. Nilai pH cenderung tidak berubah walaupun terjadi perubahan musim (Zhang et al., 2020).

\section{Analisis Sebaran DO}

Peta kontur bentuk 1D dan 3D sebaran DO dapat dilihat pada Gambar 2. Nilai DO yang paling besar ditunjukkan oleh warna biru. Semakin besar nilai DO maka menunjukkan semakin ringan tingkat pencemaran airnya. Oksigen terlarut (DO) dalam air berasal dari hasil fotosintesis oleh fitoplankton dan difusi dari udara. Nilai DO yang dapat menunjang kehidupan fitoplankton yaitu lebih dari $5 \mathrm{mg} / \mathrm{L}$. Tingginya nilai DO pada beberapa titik disebabkan karena banyaknya nutrient yang terlarut dalam air yang dapat dimanfaatkan oleh fitoplankton dalam berfotosintesis (Rahmawati \& Surilayani, 2017).

Pada penilitian ini tidak terdapat sampel yang memiliki nilai DO kurang dari 3. Rendahnya nilai DO karena kurangnya penunjang kehidupan fitoplankton dan nilai DO yang rendah juga sangat berbahaya bagi kehidupan mikroorganisme (Spanton M \& Saputra, 2017). Nilai DO akan berbeda pada setiap musim, pada musim hujan nilai DO lebih rendah dibandingkan dengan musim kemarau, karena pada musim kemarau akan meningkatkan suhu air dan memudahkan produksi oksigen oleh fitoplankton (Wu et al., 2010). 

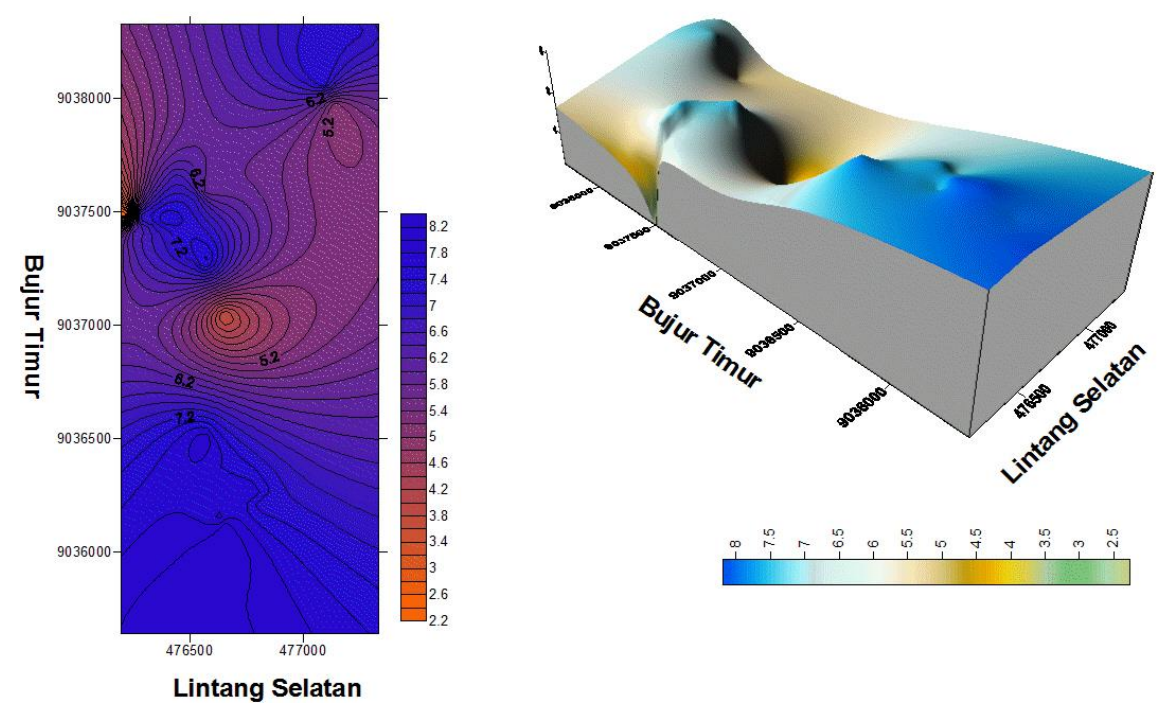

Gambar 2. Peta Kontur Sebaran DO

\section{Analisis Sebaran TDS}
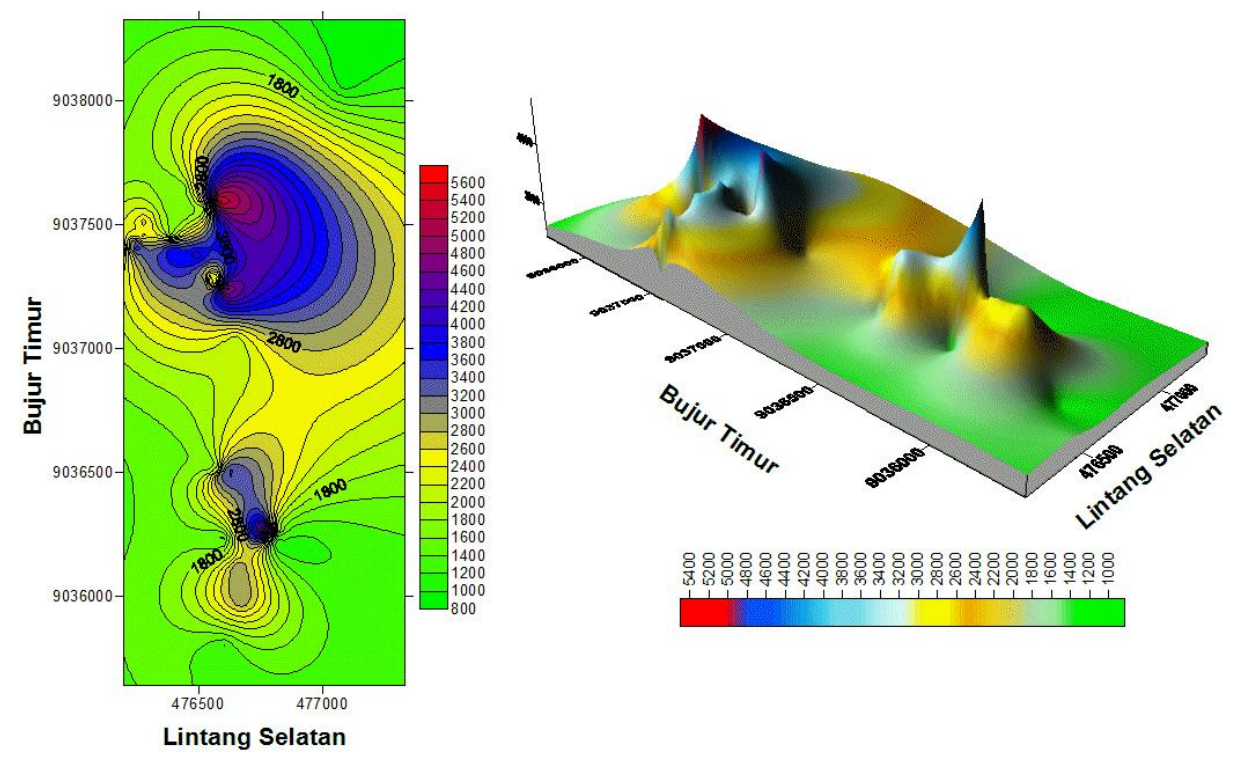

Gambar 3. Peta Kontur Sebaran TDS

Total dissolved oxygen (TDS) merupakan salah satu parameter fisika yang dapat dijadikan acuan dalam penentuan tingkat pencemaran dalam suatu perairan. TDS merupakan ukuran jumlah zat yang terlarut di dalam air, baik itu berupa zat organik maupun zat anorganik. Di 
kawasan pesisir seperti Desa Labuhan Kertasari, kemungkinan besar air tanah tercemar oleh masuknya air laut ke daratan, hal ini dapat dilihat dari nilai salinitas dan TDS (Afrianita et al., 2017). Hasil penelitian yang dilakukan (Hilmi et al., 2021), menunjukkan bahwa air tanah di Desa Labuhan Kertasari sudah mengalami pencemaran oleh air laut dan bersifat payau, dengan nilai rata-rata salinitas sebesar 1912,5 ppm. Dari Gambar 3. Dapat dilihat bahwa nilai TDS yang paling tinggi ditunjukkan dengan warna merah dan yang paling rendah ditunjukkan dengan warna hijau.

\section{Analsis Pengaruh Kedalaman terhadap TDS, pH dan DO}

Sumur warga yang dijadikan sebagai objek penelitian memiliki kedalaman yang berbedabeda, sehingga dilakukan analisis pengaruh kedalaman terhadap nilai $\mathrm{pH}$, TDS dan DO. Dari Gambar 4. Menunjukkan hubungan yang tidak linier antara $\mathrm{pH}$, TDS, dan DO dengan nilai koefisien determinasi $\left(\mathrm{R}^{2}\right)$ secara berurutan sebesar 0,1184, 0,03924 dan 0,0074. Artinya nilai $\mathrm{pH}$, TDS dan DO tidak dipengaruhi oleh kedalaman sumur. Perbedaan nilai ini dipengaruhi oleh faktor lain, seperti jarak sumur warga dari bibir pantai dan lapisan bawah permukaan yang dapat mempengaruhi nilai TDS (Hilmi et al., 2021).

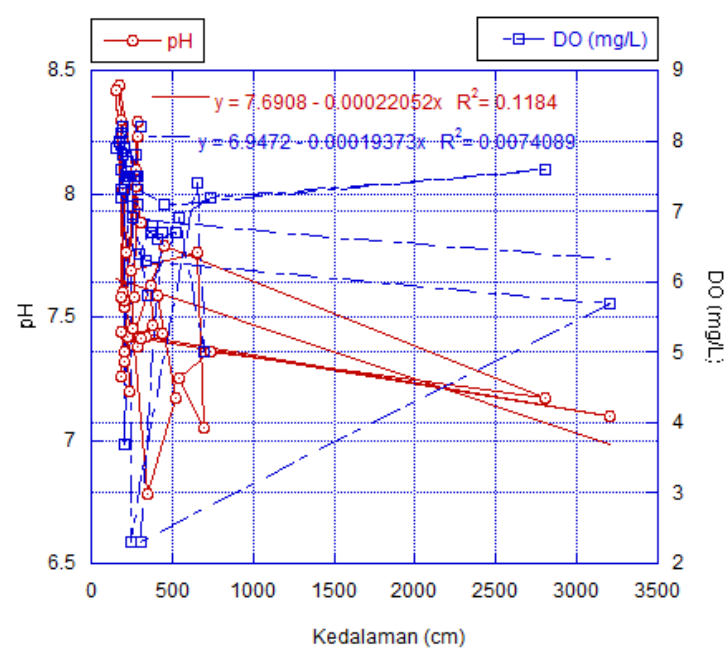

(a)

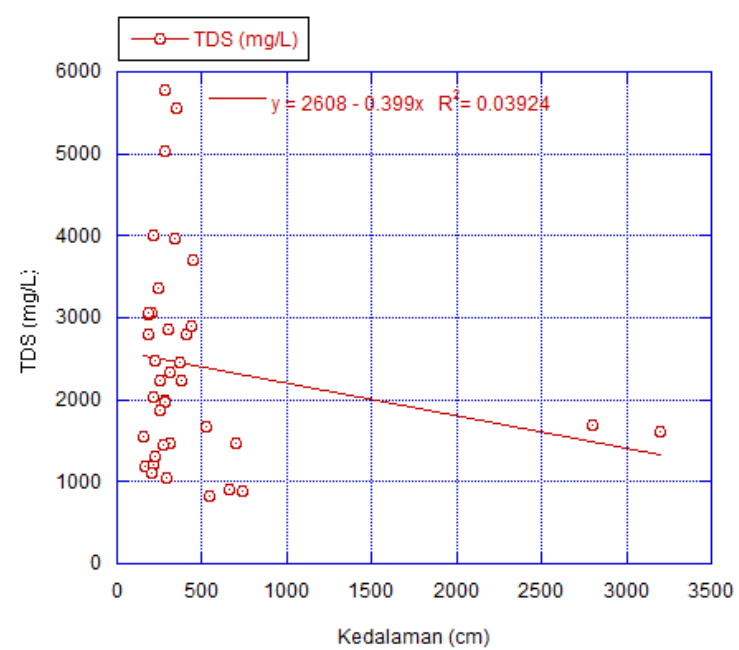

(b)

Gambar 4. Grafik hubungan pH, DO dan Kedalaman (a) dan grafik hubungan TDS dan kedalaman (b) 


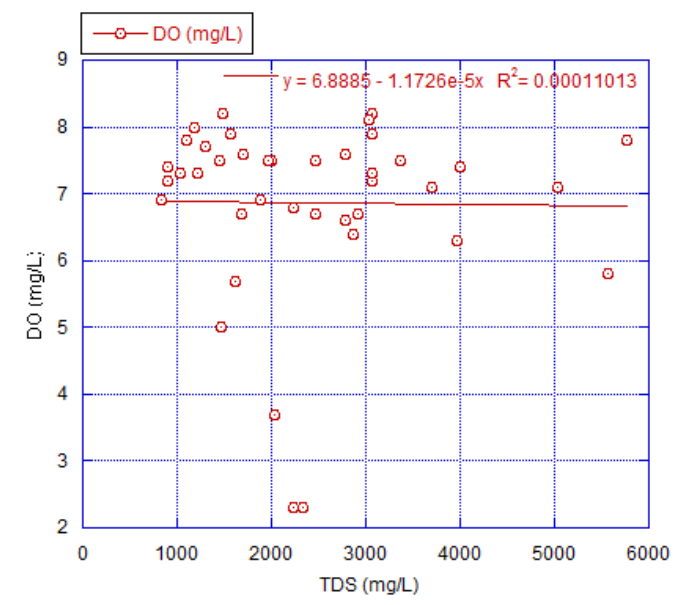

Gambar 5. Grafik hubungan TDS dengan DO

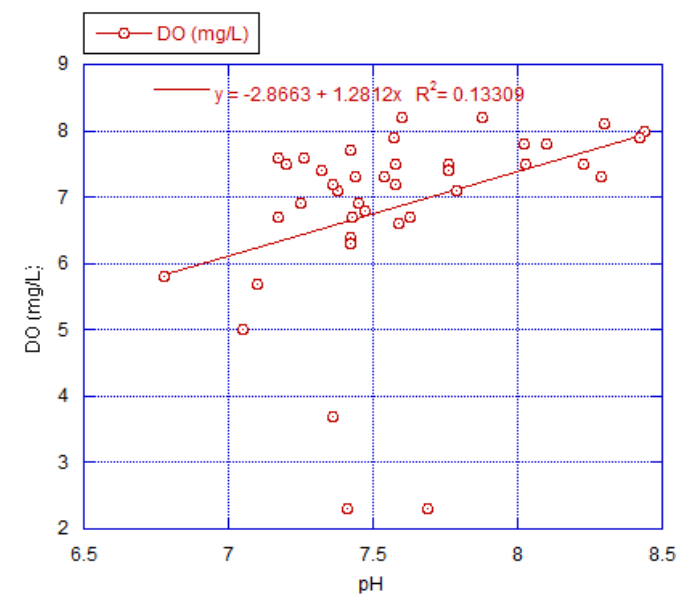

Gambar 6. Grafik hubungan pH dengan DO

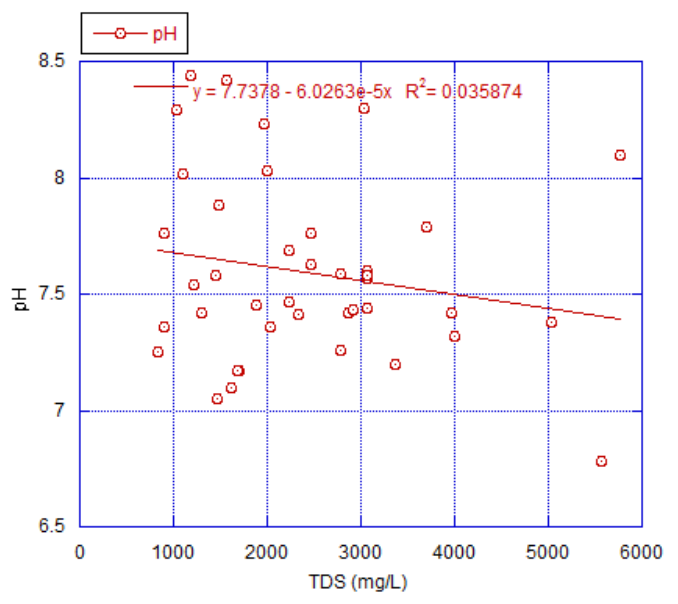

Gambar 7. Grafik hubungan TDS dengan $\mathrm{pH}$

Untuk mengetahui apakah setiap parameter yang diukur saling mempengaruhi, maka dilakukan analisis liniearitas sedarhana hubungan setiap parameter. Pada Gambar 5, TDS tidak berpengaruh positif terhadap nilai DO. $\mathrm{pH}$ air tanah juga tidak mempengaruhi nilai oksigen terlarut (DO), nilai koefisien determinasi $\left(\mathrm{R}^{2}\right)$ sebesar 0,13309. Suatu hubungan akan memiliki hubungan yang postif dan mempengaruhi satu dengan yang lain ketika nilai $\mathrm{R}^{2}$ mendekati 1 .

Gambar 7. Merupakan grafik hubungan TDS dan $\mathrm{pH}$, dari gambar dapat dilihat bahwa nilai TDS tidak mempengaruhi besarnya $\mathrm{pH}$. 


\section{KESIMPULAN}

Berdasarkan parameter $\mathrm{pH}$ dan DO dapat digolongkan kedalam kualitas air kelas I, kelas II, kelas III. Sedangkan berdasarkan parameter TDS, maka sebanyak 7,5\% sampel air yang termasuk kelas I, yaitu pada SW25, SW26 dan SW28 dengan nilai TDS berturut-turut: 893 mg/L; 836 mg/L; 904 mg/L, nilai pH berturut-turut: 7,36; 7,25; 7,76 dan nilai DO berturut-turut: 7,$2 ; 6,9 ; 7,4$.

\section{DAFTAR PUSTAKA}

Afrianita, R., Edwin, T., \& Alawiyah, A. (2017). ANALISIS INTRUSI AIR LAUT DENGAN PENGUKURAN TOTAL DISSOLVED SOLIDS ( TDS ) AIR SUMUR GALI DI KECAMATAN PADANG UTARA. Jurnal Tekknik Lingkungan, 14(1), 62-72.

Ahmad, A. Y., Al-ghouti, M. A., Khraisheh, M., \& Zouari, N. (2020). Hydrogeochemical characterization and quality evaluation of groundwater suitability for domestic and agricultural uses in the state of Qatar. Groundwater for Sustainable Development, 11(July), 100467. https://doi.org/10.1016/j.gsd.2020.100467

Ahuja, S. (2013). Monitoring Water Quality Pollution Assessment, Analysis, and Remediation. Elsevier.

Hilmi, A., Ulfa, A. M., Wijaya, A., \& Hadimi, L. I. (2021). Study of seawater intrusion in coastal aquifer using total dissolved solid, conductivity and salinity measurement in Labuhan Kertasari Village, West Sumbawa. Journal of Physics: Conference Series, 1816(012064). https://doi.org/10.1088/1742-6596/1816/1/012064

Lugra, I. W., Wahib, A., \& Zuraida, Y. D. R. (2003). Peluang Pengembangan Wilayah Pesisir Pantai Sumbawa Barat, Nusa Tenggara Barat Ditinjau dari Aspek Karakteristik dan Gejala Perubahan Garis Pantai. Jurnal Geologi Kelautan, 1(2), 1-12.

PERATURAN PEMERINTAH RI NO 82 TAHUN 2001 TENTANG PENGELOLAAN KUALITAS AIR DAN PENGENDALIAN PENCEMARAN AIR, (2001).

Rahmawati, A., \& Surilayani, D. (2017). Pengelolaan Kualitas Perairan Pesisir Desa Lontar, Banten. Jurnal Perikanan Dan Kelautan, 7(1), 59-70.

Salvi, H., Patel, R., Thakur, B. J., Shah, K., \& Parmar, D. (2014). ASSESSMENT OF COASTAL WATER QUALITY PARAMETERS OF SELECTED AREAS OF MARINE NATIONAL PARK \& SANCTUARY (OKHA, SIKKA \& KHIJADIYA). SSRN Electronic Journal.

Spanton M, P. I., \& Saputra, A. A. (2017). ANALYSIS OF SEA WATER POLLUTION IN COASTAL MARINE DISTRICT TUBAN TO THE QUALITY STANDARDS OF SEA WATER WITH USING STORET METHOD. Jurnal Kelautan, 10(1), 103-112. http://doi.org/10/21107/jk.v10i1.2671

http://dx.doi.org/10.23960/aec.v6.i1.2021.p22-32 
Wu, M.-Li., Wang, Y.-S., Sun, C.-C., Wang, H., Dong, J.-D., Yin, J.-P., \& Han, S.-H. (2010). Identification of coastal water quality by statistical analysis methods in Day Bay, South China Sea. Marine Pollution Bulletin, 60(6), 852-860. https://doi.org/10.1016/j.marpolbul.2010.01.007

Zhang, X., Zhang, Y., Zhang, Q., Liu, P., Guo, R., Jin, S., Liu, J., Chen, L., Ma, Z., \& Liu, Y. (2020). Evaluation and Analysis of Water Quality of Marine Aquaculture Area.

International Journal of Environmental Research and Public Health, 17(1446), 1-15. 